\title{
O papado avinhonense e os poderes civis: as décadas de 30 e de 40 do século XIV a partir de três obras de Guilherme de Ockham
}

\author{
Ana Paula Tavares MAGALHÃES•
}

Resumo: A negação da chamada plenitudo potestatis ao papa, por parte do menorita Guilherme de Ockham, insere-se, do ponto de vista de seu contexto histórico, no amplo movimento, processado a partir da transição do século XIII para o XIV, de declínio do Império enquanto poder universal, somado à progressiva busca pela laicização das questões de Estado, tendo como resultado a mudança na concepção da autoridade papal. Dessa forma, querelas ocorridas entre o regnum e o sacerdotium passariam a opor à autoridade papal a figura de monarcas em franca ascensão (caso da disputa entre Bonifácio VIII e Filipe IV, da França). Além disso, as novas soluções configuravam-se antes como favoráveis aos poderes civis que à autoridade papal. Um aspecto significativo da ampliação do poder e prestígio das monarquias foi a própria transferência do papado para a cidade francesa de Avinhão, a partir de 1309, sob o papa Clemente V. O referido pontífice atendia à expectativa do mesmo rei da França, Filipe IV, o qual deveria, assim como seus sucessores, ao longo dos anos seguintes, utilizar-se da instituição eclesiástica com a finalidade de opor-se a seus inimigos políticos. Um dos pontos culminantes dessa aliança ter-se-ia dado sob o pontificado de Clemente VI (1342-1352), que apoiou o monarca francês Filipe VI contra seu primo e rei da Inglaterra Eduardo III, na Guerra dos Cem Anos; e ainda, sua hostilidade concorreu para a queda do imperador Luís da Baviera. Pretende-se, nesse trabalho, avaliar as relações do papado avinhonense com os poderes civis (os reinos da França e da Inglaterra e o Império), entre fins da

- Professora Doutora - Departamento de História - Faculdade de Filosofia, Letras e Ciências Humanas - Universidade de São Paulo USP - 05508-900 - São Paulo - SP - Brasil. E-mail: apmagalh@usp.br 
década de 30 e inícios da década de 40 do século XIV. Para tanto, partiremos das obras Pode um príncipe, Consulta sobre uma questão matrimonial e Sobre o poder dos imperadores e dos papas, de Guilherme de Ockham.

Palavras-Chave: Papado avinhonense; Luís da Baviera; Reino da França.

A negação da chamada plenitudo potestatis ${ }^{1}$ ao papa, por parte do menorita inglês Guilherme de Ockham (c.1285-c.1347), relaciona-se, do ponto de vista do conjunto da obra do autor, a um de seus grandes temas, a saber, aquele da liberdade, podendo-se estabelecê-la como uma "atualização particular de um dos temas maiores de toda sua obra." ${ }^{2}$ Com efeito, a concepção ockhamiana do poder papal vincula-se a suas posturas de caráter epistemológico, presentes em sua produção filosófica. Assim, o nominalismo encarava a Igreja como a soma dos indivíduos que constituíam o conjunto dos fiéis, em detrimento de concebê-la como uma corporação, que, no entender do menorita, era apenas um conceito mental. De acordo com Falbel, a Ecclesia encontrar-se-ia, portanto, sujeita, em sua organização e em sua autoridade, à vontade de seus membros individuais, sendo o todo a soma de suas partes ${ }^{3}$. Assim, à recusa da plenitudo potestatis ao papa na esfera espiritual correspondia, entre outros aspectos, a defesa da liberdade do imperador e dos governantes civis em geral; e sua negação no âmbito temporal coadunava-se com a formulação ockhamiana a respeito da liberdade contida na Lei evangélica.

Por outro lado, do ponto de vista de seu contexto histórico, a referida recusa insere-se no amplo movimento de declínio do Império, processado a partir da transição do século XIII para o $\mathrm{XIV}$, enquanto poder universal, somado à progressiva busca pela laicização das questões de Estado, tendo como resultado a mudança na concepção da autoridade papal. Dessa forma, querelas ocorridas entre o regnum e o sacerdotium passariam a 
querelas ocorridas entre o regnum e o sacerdotium passariam a opor à autoridade papal a figura de monarcas em franca ascensão (caso da disputa entre Bonifácio VIII e Filipe IV, da França). As novas soluções configuravam-se antes como favoráveis aos poderes civis que à autoridade papal. Assim, de acordo com Marcel Pacaut, a luta, que então confrontava o papa não mais com o imperador, mas com o rei da França, era representativa do declínio da instituição imperial e do fortalecimento dos Estados; além disso, ainda de acordo com Pacaut, a luta não terminaria com a vitória do papa ou por meio de um acordo favorável a ele, o que viria a significar um processo de declínio da autoridade política dos papas ${ }^{\mathrm{iv}}$.

Costumam-se identificar, no conjunto das relações entre Bonifácio VIII (1294-1303) e Filipe IV (1285-1314), dois litígios fundamentais. Trata-se de questões destituídas de importância, se consideradas isoladamente. Acabaram, entretanto, por assumir um significado decisivo em função do contexto em que ocorreram ${ }^{v}$. Com efeito, os últimos anos do século XIII e os primeiros do XIV assistiram aos esforços do pontífice no sentido de recuperar aspectos teóricos e o exercício de sua autoridade tal qual se apresentavam durante o papado de Inocêncio III (1198-1216). Porém, tão significativo quanto seus esforços foi o malogro de sua empresa. A argumentação revelava-se pouco adequada ao período em questão: com efeito, observava-se, naquele momento, uma defasagem entre as pretensões do pontífice e a nova ordem social e política. Nela, verificava-se a presença de reis preocupados em consolidar seu poder político (que, neste momento, significava forjar o próprio Estado), cuja preservação e desenvolvimento surgiam como seu primeiro dever - era o caso, ressalvado o risco de incorrermos em precipitação, de Filipe IV. Além disso, ganhava importância a chamada burguesia, ligada à pequena nobreza, que se acreditava encarregada de defender a nova cultura política.

Um aspecto significativo da ampliação do poder e do prestígio das monarquias foi a própria transferência do papado para a cidade francesa de Avinhão, a partir de 1309, sob o papa Clemente V. O referido pontífice atendia à expectativa do 
mesmo rei da França, Filipe IV, o qual deveria, assim como seus sucessores, ao longo dos anos seguintes, utilizar-se da instituição eclesiástica com a finalidade de opor-se a seus inimigos políticos. Após a morte de Bonifácio VIII, Filipe IV seguiu empenhado em realizar o processo do defunto, tendo sido dissuadido somente quando seu sucessor, Bento XI (1303-1304), invalidou todas as condenações ao rei e a seus conselheiros. Por fim, num ato final de submissão, o sucessor de Bento, Clemente $\mathrm{V}$ (1305-1314), invalidou todas as atas que pudessem lesar o rei e transferiu a sede pontifícia para a cidade francesa de Avinhão (1309). Dessa forma, apesar dos esforços envidados por uma série de papas do século XIV - entre eles João XXII (1318-1334), Bento XII (1334-1342) e Clemente VI (1342-1352) - no sentido de sobrepor sua autoridade aos poderes civis constituídos, o contexto social e político revelava a defasagem de sua argumentação.

Durante o pontificado de João XXII (1318-1334), observa-se o auge do centralismo da Igreja em torno da figura do papa, que se tornaria uma característica marcante de todo o papado avinhonense - concluído em 1377, com Gregório XI (1370-1378). João XXII demonstrava personalidade frugal e austera em termos políticos, em contrapartida, sublinhou a grandeza do papado, defendendo a tese de sua superioridade sobre o Império, bem como aquela de que o poder do imperador proviria do papa, bem como caberia a ele o direito de nomeá-lo, controlálo e julgá-lo - postura que seria endossada por seus sucessores, a saber, Bento XII (1334-1342) e Clemente VI (1342-1352). Promoveu uma reforma financeira e administrativa, aumentou o controle sobre nomeações episcopais e sobre as ordens monásticas e estendeu a toda a Europa o sistema de tributação papal (anatas), além de reorganizar o código da lei canônica. Além disso, ao instalar-se em Avinhão, a corte papal livrou-se do envolvimento com as complexas e antiqüíssimas vendetas familiares da nobreza romana, tornando-se, mais do que nunca, o centro administrativo e jurídico da Igreja. Assim, se os papas do início da Idade Média extraíam seu poder das relíquias dos 
apóstolos, os do período de Avinhão retiravam-no de sua sofisticada burocracia e de seu sistema de finanças papais.

Para além das questões propriamente burocráticas, suas concepções doutrinárias conduziram a querelas que só começariam a resolver-se sob os pontificados de seus sucessores, a saber, Bento XII e Clemente VI. Trata-se, entre outros aspectos, da questão franciscana. João XXII hostilizou os chamados Espirituais Franciscanos - elementos radicais no interior da ordem que pretendiam restaurar aquilo que consideravam a intentio de São Francisco de Assis, apregoando o extremo rigor no cumprimento da regra -, bem como parte dos moderados, ao condenar, por meio de três constituições ${ }^{\mathrm{vi}}$, a doutrina segundo a qual as Escrituras provavam que Cristo e os apóstolos nada haviam possuído, quer em caráter comum, quer em particular. Repudiou, ainda, o acordo segundo o qual os papas eram os proprietários nominais dos bens da Ordem Franciscana ${ }^{\text {vii }}$, dispondo esta somente do seu usufruto. E no ano de 1318, na cidade de Marselha, determinou a queima de quatro Espirituais Franciscanos, com base na referida afirmação. Com isso, atraiu a oposição por parte dos dirigentes da ordem, que acabaram por dirigir-se a Avinhão, por volta do ano de 1328, a fim de protestar - dentre eles, encontrava-se o então ministro geral da Ordem, Miguel de Cesena.

No entanto, as reformas empreendidas por esses pontífices deixaram atrás de si uma série de problemas. Assim, se por um lado o centralismo decisório tendia a eliminar contendas locais e melhorar o padrão dos nomeados - era o caso, por exemplo, das eleições episcopais -, por outro violou uma série de direitos existentes, criando expectativas na disputa pelos cargos, as quais não eram passíveis de ser satisfeitas pelos papas.

Em um contexto em que a França, a Inglaterra e a Alemanha encontravam-se em conflito, o fato de boa parte da renda papal provir de tributos da Inglaterra e da Alemanha suscitou ressentimentos, e sobretudo a acusação de que os recursos das igrejas inglesa e alemã estavam sendo devorados pela França (sede e patrocinadora dos novos papas). A complexidade da administração papal acarretava novas 
necessidades e desenvolveu uma burocracia muito numerosa, o que comprometia as relações dos papas da cidade francesa com o clero e os governos dos países vizinhos. Ainda no Concílio de Viena (1311), reunido sob Clemente V, Guilherme Durand, bispo de Mende, propunha a reversão da tendência ao centralismo em favor de um maior fortalecimento das hierarquias locais e dos sínodos regionais. Nada resultou de suas propostas, e o descontentamento, naturalmente, cresceu.

As provisões papais, assim aumentadas, eram, muitas vezes, esbanjadas. Clemente VI, definido como homem caridoso, teria permanecido em Avinhão durante a peste (que dizimou a cidade, matando mais de 62 mil habitantes), a fim de supervisionar o atendimento aos enfermos, os enterros e a assistência pastoral aos moribundos. Mas era também um anfitrião bastante pródigo, ao qual são atribuídas sentenças como "um papa deve fazer felizes os seus súditos", e "os meus antecessores não sabiam ser papas". Outra parte do dinheiro era empregada nas guerras intestinas italianas, já que os papas lutavam à distância para conservar seu patrimônio na Itália. Calculou-se que João XXII teria gasto em guerras $63 \%$ de seus rendimentos; estima-se que dois terços de toda renda auferida pelo papado de Avinhão destinaram-se à manutenção de exércitos mercenários e ao suborno de aliados na política italiana $^{\text {viii }}$.

Os papas - que, a partir do decreto de Nicolau II a respeito da eleição pontifícia, em 1059, eram escolhidos, preferencialmente, entre os prelados romanos ${ }^{\text {ix }}$ - passaram a ser recrutados no clero francês. Com efeito, os sete indivíduos que ocuparam o trono de Pedro em seu período avinhonense eram de proveniência francesa. $\mathrm{E}$ a interferência do monarca francês em sua escolha era indubitável.

Bom exemplo da situação acima exposta, Clemente VI, o quarto papa de Avinhão, era um produto da corte francesa. Havia galgado postos na hierarquia eclesiástica antes a serviço do rei da França que da Igreja. Desenvolveu uma política estreitamente vinculada aos interesses do monarca francês, 
tendo seu pontificado inspirado a comum imagem do papado de Avinhão como instrumento do rei da França. Clemente seguiu a linha francesa particularmente nas relações do rei Filipe VI (1328-1350) com seu primo e rei da Inglaterra, Eduardo III (13271357), ao longo da chamada Guerra dos Cem Anos (1337-1453); e com Luís da Baviera (1314-1347), o imperador, contra o qual seus dois antecessores (João XXII e Bento XII) já haviam nutrido animosidades por questões de doutrina. Por fim, sua hostilidade acabou por ser um dos componentes que conduziram à queda do bávaro.

É no cruzamento dessas questões - que envolvem relações de poder entre a França, o papado (sob Bento XII e Clemente VI, respectivamente), a Inglaterra e o Império, bem como, paralelamente, os conflitos entre os poderes civil e eclesiástico que se situa a produção de três importantes tratados do franciscano inglês Guilherme de Ockham: Pode um príncipe (1338), Consulta sobre uma questão matrimonial (1341-1342) e Sobre o poder dos imperadores e dos papas (1347) ${ }^{\mathrm{x}}$. Trata-se de opúsculos representativos das questões políticas fundamentais das décadas de 30 e de 40 do século XIV.

Entre fins do século XIII e inícios do XIV, uma das questões mais recorrentes no conjunto das relações de poder entre a Igreja e a autoridade civil era aquela da taxação real ou imperial sobre os bens do clero a fim de financiar empreitadas bélicas. O precedente fora aberto pelo próprio papa Inocêncio III, e o exemplo foi seguido por monarcas como Filipe, o Belo. O tema foi abordado por Guilherme de Ockham no opúsculo intitulado An princeps. Trata-se de uma abreviação, julgada adequada a um tratado cuja autoria de Ockham só foi comprovada em 1911, por Richard Scholz ${ }^{\mathrm{xi}}$. A despeito disso, não se encontrou, no corpo do texto, um título que pudesse ser seguramente atribuído ao menorita. Desde 1336, Eduardo III, da Inglaterra, pretendia que o clero inglês pagasse um imposto de $10 \%$ sobre suas propriedades. O montante destinava-se a promover a guerra contra seu primo Filipe VI, de Valois (13281350), rei da França e sucessor do último capetíngio, Carlos $X$ (1328), que não deixara herdeiros masculinos. Eduardo III era 
neto de Filipe, o Belo (1285-1314) pelo lado materno, ao passo que o Valois era sobrinho do rei. A declaração formal de guerra ocorreria em julho de 1337. Entretanto, o clero encontrava-se proibido de auxiliar governantes civis sem a prévia autorização da Santa Séxii. Além disso, o papado, instalado em Avinhão por Clemente V em 1309, encontrava-se sob o patrocínio e a proteção do rei da França, e os pontífices favoreciam os interesses políticos dos monarcas franceses, configurando-se como seus aliados naturais. E ainda, o papa Bento XII censurava Eduardo III por sua aliança político-militar com o imperador Luís IV - seu aliado natural, se consideradas as oposições à monarquia francesa e ao papado por parte da Inglaterra e do Império, respectivamente -, tido como inimigo da Sé Avinhonense e excomungado tanto por João XXII quanto pelo próprio Bento XII. Quando, em 1338, Eduardo assumiu o título de vigário imperial na Gália Oriental (atuais Bélgica e Holanda), o papa passou a ameaçá-lo com a excomunhão. Tratava-se de regiões sob a suserania da França, a partir das quais o rei da Inglaterra poderia invadir $o$ reino francês. Acabou por excomungá-lo quando Eduardo, de posse do condado de Flandres, atacou as possessões do bispo de Cambrai. Diante das novas circunstâncias, em nome da manutenção de boas relações com a Santa Sé, Eduardo afrouxou a aliança com o imperador, embora não tenha desistido do trono francês, razão pela qual prosseguiu na luta contra seu primo.

Nesse momento, Guilherme de Ockham, inglês radicado em terras imperiais desde 1328 - que jamais retornara à Inglaterra depois de sua convocação junto ao papa, em Avinhão, em 1324 - e desde a mesma data ferrenho opositor do papado,

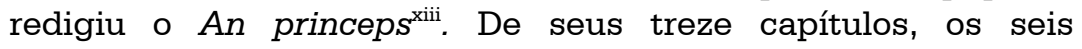
primeiros destinavam-se a negar a plenitudo potestatis ao papa, refutando as teses curialistas - apoiando-se, para tanto, na liberdade evangélica e na preeminência do imperador -, tema recorrente em toda a sua obra política. Os sete últimos destinavam-se à finalidade específica de demonstrar que os prelados e clérigos da Inglaterra encontravam-se obrigados a 
ajudar o rei, inclusive com os bens eclesiásticos, no caso de uma guerra justa $^{\text {xiv }}$. Sem nos determos à primeira parte da obra, que traz aspectos recorrentes no conjunto do pensamento do frade $\mathrm{e}$ que não serão objeto de análise aqui, passemos à análise dos momentos que se destinam a responder à pergunta contida no título.

O primeiro argumento a favor de provar a resposta afirmativa à assertiva do título é o seguinte: por intermédio de um direito humano, e não divino, os referidos bens, sob a forma de rendas ou propriedades, pertenciam à Igreja. Assim, tudo aquilo que era possuído pelos clérigos da Inglaterra fazia parte do domínio que, na verdade, pertencia ao rei da Inglaterra: "Esse dado é confirmado por Agostinho, o qual, na primeira parte de seu Comentário ao Evangelho de São João, quase ao final do sexto sermão (...), diz o seguinte: 'Mediante qual direito, o divino ou o humano, apelas para reivindicar os bens da Igreja? Eles responderam: o direito divino se encontra na Sagrada Escritura, enquanto o humano se acha nas leis dos reis. Por força de qual direito, então, cada pessoa detém o que possui? Não é, talvez, por força do direito humano? De fato, graças ao direito divino, ao Senhor pertence toda a terra e o que nela contém [S] 23,1]. Deus fez os ricos e os pobres com o mesmo limo, e a mesma terra os sustenta. Logo, é mediante o direito humano que se diz: esta vila, esta casa, este servo são meus. (...)'" ${ }^{\mathrm{xv}}$.

O segundo argumento é que, na esfera temporal, cabia ao rei da Inglaterra, primeiro possuidor dos bens, estabelecer de que forma estes deveriam ser distribuídos, sobretudo os supérfluos, bem como o uso que os clérigos deveriam fazer deles. Assim: "qualquer um que deseje legar, oferecer ou dar algo que lhe pertença pode impor uma norma ou condição, desde que não esteja proibida pela lei superior. (...) Disso evidentemente se infere que os reis da Inglaterra e os seus súditos podiam estabelecer de qual modo deviam ser distribuídos quaisquer bens temporais e possessões, precipuamente os supérfluos, e qual o uso que os clérigos tinham de lhes atribuir. E qual determinação, vontade, intenção, eles tinham o dever de respeitar, como se se tratasse de algo 
necessário à sua salvação, não obstante haver uma proibição, preceito ou decreto de alguém, o qual não deve ser considerado como superior aos reis na esfera temporal." ${ }^{\mathrm{xvi}}$

O terceiro argumento é que os bens temporais, sobretudo os supérfluos, foram dados aos clérigos pelos reis, príncipes e outros leigos para serem empregados em causas pias. Finalmente, o quarto aspecto é que "causas pias", expressão generalizante, deve ser interpretada de forma a promover vantagens ao bem comum. Assim, "deve-se fazer uma interpretação mais equânime, humana, razoável e verossímil, como, de fato, ao se julgar as questões concernentes ao culto divino, 'deve-se fazer uma interpretação benévola', de acordo com o que está estipulado no Livro Extra das Decretais. Do mesmo modo que, ao se estabelecer quais ações são meritórias, deve-se fazer uma interpretação mais equânime e razoável, que não seja capciosa para ninguém, de acordo com o que está estipulado no Digesto e, igualmente, tudo que está dito de modo obscuro deve ser interpretado de maneira a assegurar a maior vantagem, particularmente ao bem comum, e a não redundar em prejuízo injusto a ninguém." xvii

A alusão aos pontífices e a seu comportamento a respeito das rendas auferidas pela Sé avinhonense também é sugerida, bem como o excessivo centralismo papal. Assim, Guilherme de Ockham conclui que "a Igreja de Avinhão, ao ordenar algo e ao dispor dos bens eclesiásticos dos clérigos seculares ou regulares diferentemente da maneira estipulada por aqueles que os doaram, a saber, tirando deles e os tomando para si ou doandoos para outros clérigos, os prejudica. É por isso que o papa, ou aquele que administra em nome do papa, se dá dízimos ou uma outra determinada parcela dos bens supérfluos pertencentes aos clérigos a algum clérigo ou leigo ou ainda os toma para si, os prejudica de maneira evidente, a não ser que o doador dos bens aos clérigos tenha concedido ao papa tal poder para fazer isso. É por essa razão igualmente que o papa absolutamente não pode imiscuir-se no assunto relativo aos bens que foram doados às igrejas, uma vez que não se encontra escrita tal coisa nos 
privilégios dos príncipes que lhes ofertaram bens, visto que não concederam ao papa tal poder sobre os bens que doaram às igrejas. Por isso, também, se o imperador, ou um rei ou um príncipe [quiser] ser ajudado, no tocante à realização de suas causas piedosas, com os bens supérfluos da igreja, os quais ele ou os seus predecessores lhe doaram, não deve pedir subsídio ao papa no que respeita a tais bens, mas, por autoridade própria, em caso de necessidade, ele pode postular um subsídio das igrejas, a menos que, talvez, o papa, por causa de um costume sabiamente tolerado em alguma região, tenha recebido esse poder." xviii

A proximidade física com o imperador Luís da Baviera (Guilherme de Ockham exilou-se na corte imperial, em Munique, juntamente com outros frades menores, quando do início das perseguições conduzidas por João XXII, no ano de 1328) e o estímulo a uma produção de obras polêmico-políticas (voltadas para a defesa dos interesses imperiais e contra as investidas papais sobre o Império) fizeram do franciscano inglês, ao lado de figuras como Marsílio de Pádua (c.1280-c.1342) - também residente, por essa época, na corte do bávaro - um conselheiro e um ideólogo dos direitos do império contra as pretensões papais. Para além de seus elementos gerais e comuns - que incluem a recusa da plenitudo potestatis ao papa e a defesa da anterioridade do Império em relação ao papado -, algumas de suas obras atenderam à urgência específica da polêmica do momento. É o caso - como já ocorrera com o Pode um príncipe de dois outros tratados, desta vez destinados particularmente ao imperador: Consulta sobre uma questão matrimonial e Sobre o poder dos imperadores e dos papas.

Com efeito, a política desenvolvida pelo papa Clemente VI junto a seu aliado, o monarca francês Filipe VI, de Valois, bem como junto aos eleitores do Império, acabou por originar a situação que precipitou a queda do próprio imperador. Trata-se de sucessivas questões que, ao longo das décadas de trinta e de quarenta do século XIV, envolveram as grandes casas senhoriais do Império, num conflito que associava disputas territoriais e relações de poder. Luís IV, o imperador, dito da Baviera, 
pertencia à família dos Wittelsbach, originária daquela região; o rei João da Boêmia e seu irmão, o arcebispo Balduíno de Treves, por sua vez, pertenciam à casa dos Luxemburgo; por fim, havia os Habsburgos, poderoso clã austríaco, que se tornaria hegemônico na Europa do século XVII.

O Luxemburgo João da Boêmia tinha dois filhos, a saber, o primogênito Carlos (da Morávia) e João Henrique. Em 1330, arranjou para este último, que contava apenas nove anos, um casamento com Margarida, de doze anos de idade, filha de Henrique e prima em terceiro grau do imperador. $O$ pai de Margarida detinha o governo do Tirol-Caríntia desde a morte de seu pai, Meinhard II de Goerz-Tirol (1258-1295). Este, que já dominava o Tirol enquanto vassalo dos bispos de Trent e Brixen, recebeu, em 1286, o ducado da Caríntia como feudo imperial de Rodolfo de Habsburgo. Com isso, passou a ser reconhecido como um príncipe do Império. A região seria anexada ao já considerável domínio dos Luxemburgo quando o pai de Margarida morresse, de forma que o imperador prometeu 0 mesmo governo ao Habsburgo Leopoldo da Áustria. A morte de Henrique precipitou a guerra entre os Luxemburgo e os Habsburgo, ao mesmo tempo que se deterioravam as relações entre os Luxemburgo e o imperador. Este buscou uma solução conciliatória para a questão: o governo da Caríntia caberia aos Habsburgo e o do Tirol, aos Luxemburgo. Mas o conflito encontrava-se sobremaneira avançado e a tentativa de conciliação revelou-se tardia, de forma que as retaliações prosseguiram.

Em 1340, desejando assegurar o domínio dos Luxemburgo sobre o Tirol, por ocasião de uma revolta de seus habitantes contra o impopular João Henrique, o patriarca João da Boêmia enviou à região tropas comandadas por seu filho mais velho, Carlos da Morávia. Dois fatos convergiram neste momento: por um lado, a insatisfação dos tiroleses com o cerco militar e, por outro, a ausência de prole no casamento de Margarida e João Henrique. Finalmente, no início de 1341, com um exército de vassalos, Margarida expulsou do Tirol as tropas 
de Carlos; em seguida, ao fim do mesmo ano, uma revolta de nobres apoiada por Luís da Baviera expulsou da região o próprio João Henrique, a partir de então separado de Margarida. Esta, em seguida, aceitou casar-se com Luís, marquês de Brandenburgo e irmão do imperador, o que pressupunha o reforço do domínio dos Wittelsbach no Império, que passaria a estender-se para o sul da Bavária e para as rotas alpinas em direção à Itália. No entanto, dois obstáculos impunham-se à união: o casamento anterior de Margarida com João Henrique e a consangüinidade entre os noivos. A situação deveria resolverse por meio de uma licença papal para a realização do casamento.

Bento XII que, assim como seu antecessor, encontrava-se em conflito com o Império, recusou-se a examinar a causa, e secundou a negação com uma ameaça de excomunhão. Coube, portanto, aos conselheiros da corte imperial, Marsílio de Pádua e Guilherme de Ockham, a análise da situação, que se colocava nos seguintes termos: tratava-se de saber se Luís IV, por sua condição de imperador, encontrava-se habilitado a decidir a respeito daquelas duas causas. O primeiro redigiu, então o Defensor minor, tratado que consistia numa espécie de resumo de alguns de seus argumentos de sua mais célebre obra, o Defensor pacis, mas destinava-se a determinar a autoridade competente para decidir em matéria de divórcio. Concluía, com base em todo um conjunto anterior de argumentos, que o poder de dar a sentença, nesse caso, era "ad principantem auctoritate legislatoris humani". O mesmo valia também para a questão da dispensa de um impedimento de consangüinidade, já que não se tratava de matéria pertinente à lei divina ${ }^{\text {xix }}$. Nesse mesmo contexto, entre os últimos meses de 1341 e janeiro de 1342, Guilherme de Ockham redigiu o opúsculo Consulta sobre uma questão matrimonial. Há também a hipótese de que o tratado fora composto pouco antes, a dar-se crédito ao fato de o acordo Wittelsbach ter sido selado antes da expulsão de João Henrique do Tirol, no início de novembro de 1341. Um dos elementos fundamentais da argumentação do menorita nesse tratado, variação de um dos tópicos gerais de sua argumentação, é 
aquele pelo qual o imperador, descendente dos imperadores romanos, fossem eles pagãos ou cristãos, herdou deles todo o poder que possuíam, uma vez que a religião cristã, ao ser instituída por Cristo, não suprimiu o direito daqueles que governavam. A esses cabia examinar e julgar a respeito do casamento, uma instituição também anterior ao cristianismo, dotada de caráter natural e social. Ao transformá-lo em sacramento, o cristianismo não havia alterado sua essência. São palavras de Ockham, no referido tratado: “... o bem-aventurado Ambrósio, comentando a Epístola a Tito, afirma: 'A religião cristã a ninguém prive de seu direito'xx, e o bem-aventurado Agostinho, no seu Comentário ao Evangelho de João, alude, dizendo acerca da pessoa de Cristo: 'Ouvi, ó judeus e gentios [ouve ó circuncisão], ouve prepúcio, ouvi todos os reinos da terra. Não impeço a vossa dominação neste mundo, 'porque o meu reino não é deste mundo.'[Jo 18,36]"xxi Além disso, nada havia na lei natural ou no Novo Testamento que proibisse o casamento entre parentes, e o imperador poderia muito bem, ocasionalmente, em circunstâncias de caráter político, intervir na esfera espiritual. Além disso, a lei divina não proibia, de forma alguma, o casamento do irmão do imperador com a condessa da Caríntia, considerando que entre ela e o filho do rei da Boêmia jamais houvera casamento verdadeiro (tendo em vista a ausência de prole) $)^{\text {xxii }}$.

Os Luxemburgo, por sua vez, reagiram aproximando-se dos inimigos de Luís IV: de um lado, o rei da França, Filipe VI, em guerra com seu primo, Eduardo III (1327-1357), da Inglaterra - e aliado natural do imperador - e, de outro, o novo papa, Clemente VI. Este enrijecera as posturas do papado diante do imperador, de forma semelhante a João XXII. Para além da natural aliança com o rei francês, alinhou sua política àquela das casas senhoriais inimigas do bávaro, e passou a ameaçá-lo com novas excomunhões.

Em primeiro lugar, por intermédio de missivas e constituições, o papa passou a exigir do imperador a submissão a seu poder e jurisdição. À recusa de Luís IV, Clemente VI 
passou à ação, onde esta lhe cabia, em termos concretos: substituiu o arcebispo de Colônia, Henrique de Virneburg, aliado do imperador, pelo jovem Gerlach de Nassau e, com a medida, acabou por intimidar o arcebispo de Mogúncia. No ano de 1344, conclamou os príncipes eleitores a eleger um novo rei da Alemanha que deveria, mais tarde, ser coroado imperador. No dia 13 de abril de 1346, ordenou aos príncipes que depusessem o imperador por intermédio de uma guerra justa e procedessem a uma eleição, que ocorreu em 11 de julho do mesmo ano. Carlos de Luxemburgo foi coroado rei da Alemanha e imperador no dia 26 de novembro de 1346. Sem jamais ter retomado a coroa, Luís veio a falecer em 11 de outubro de 1347. O evento teria, em parte, motivado Guilherme de Ockham a redigir seu último tratado, intitulado Sobre o poder dos imperadores e dos papas, entre fins de 1346 e inícios de 1347, já que o próprio menorita morreu, provavelmente, em 1347.

Trata-se, como já se viu, da última obra do menorita cuja autenticidade foi comprovada. Além disso, a data provável de sua conclusão aproxima-se muito da própria morte de Guilherme. O título, De imperatorum et pontificum potestate, sob o qual o tratado tornou-se conhecido nos tempos modernos, não foi atribuído pelo autor, assim como não descreve por completo a substância do opúsculo, dividido, a saber, em três grandes partes: a primeira destina-se a negar a plenitudo potestatis aos papas de Avinhão, como se verá em seguida; a segunda, ao confrontar os direitos dos governantes seculares particularmente aqueles do "Império Romano", antecessor direto do Sacro Império Romano-Germânico - e os do papa, parece ser a responsável pelo título tardiamente atribuído ao tratado; a terceira parte da obra, mais extensa do que as demais, destinase a acusar de heresia o papa João XXII (1318-1334), tema recorrente em sua obra, afirmando a continuidade de suas posturas nas figuras de seus sucessores: Bento XII (1334-1342) e Clemente VI (1342-1352). Por isso, nenhum deles possuía legitimamente o título de sumo pontífice, devendo ser considerados usurpadores da cátedra de Pedro. A heresia em questão dizia respeito à doutrina da pobreza absoluta de Cristo, 
elemento de confronto com alguns membros da Ordem Franciscana.

Assim, o título, não original da obra, parece derivar de um cabeçalho, adicionado ao texto de seu mais antigo manuscrito pelo bibliotecário real Patrício Young, no século XVII: Gulielmus

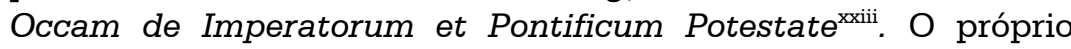
Guilherme endereçava o trabalho, sob seu próprio nome, a todos os cristãos, à maneira de uma carta aberta, e pareceu não necessitar de um título para tanto ${ }^{\text {xxiv }}$. Em contrapartida, podemos aqui notar novamente seu caráter de obra de síntese, como ocorrera também em relação ao Brevilóquio sobre o principado tirânico ${ }^{\mathrm{xxv}}$.

O tratado destinava-se a provar, entre outros aspectos, mais uma vez, que os papas de Avinhão transgrediam os direitos das autoridades políticas - sobretudo os do imperador ao atuar para além dos limites estabelecidos para o poder espiritual no mundo. Violavam, também, os direitos dos fiéis em geral, ao buscar impor um domínio despótico contrário à lei evangélica. Dessa forma, contra as pretensões do papado avinhonense de exercer a plenitudo potestatis nos âmbitos temporal e espiritual, Guilherme de Ockham opunha o princípio de que a plenitude do poder - entendida como o poder absoluto quer no âmbito temporal, quer no espiritual, desde que não se oponha às leis natural e divina - não era uma atribuição dos pontífices, já que:

A) sendo o império anterior à instituição eclesiástica, seu poder não poderia provir dela e nem a ela submeter-se, tendo sido instituído por Deus com o concurso da ordenação humana portanto, não caberia ao pontífice o exercício da plenitudo potestatis no âmbito temporal. Dessa forma, "o império romano existiu antes do papado; logo, em sua origem, não surgiu por intermédio do papa (...). Disso segue-se que se o papa se intrometer em algo que é da alçada do império romano, contra a permissão daqueles a quem compete tomar qualquer disposição relativa ao mesmo, ou proceder de outro modo, diferente de como age em relação aos outros reinos, ou contra o que foi estabelecido 
pelos imperadores, vago ou não o trono imperial, prejudica o império romano, 'metendo a sua foice em messe alheia'xxvi, porque ele não obteve tal poder sobre o império romano, nem por força do direito divino, nem do humano."xxvii

B) o exercício de um tamanho poder é avesso à liberdade contida na lei evangélica - e que a distingue da mosaica -, devendo o poder instituído por Cristo a Pedro e a seus sucessores ser entendido como de serviço, e não dominativo - portanto, não caberia ao pontífice também o exercício da plenitudo potestatis no âmbito espiritual. "Daí, Cristo, ao estabelecer o bemaventurado Pedro como guia de suas ovelhas, não lhe ter dito: 'tosquia as minhas ovelhas e fabrica vestes para ti com a sua lã', nem tampouco lhe falou: 'ordenha as minhas ovelhas e bebe do seu leite', muito menos afirmou: 'mata as minhas ovelhas e come de sua carne'. Antes lhe ordenou: 'Apascenta as minhas ovelhas' (Jo 21,17), quer dizer, 'guarda, protege, defende e serve as minhas ovelhas em proveito das mesmas e para a minha glória'."xxviii

A alusão particular à questão da deposição do imperador e à eleição do anti-imperador foi aquela que permitiu que se procedesse à datação do último trabalho de Ockham. Com efeito, ele teria sido produzido entre novembro de 1346, quando da coroação de Carlos de Luxemburgo, em abril de 1347, presumida data da morte do próprio Ockham. Dentre as passagens, citamse as presentes nos capítulos XXII e XXIII: "Além disso, esses indivíduos (papas de Avinhão), movidos pela ambição de dominar e completamente cegos por tamanha fúria de avidez e de rapacidade, desejam submeter a si o império romano, não deixando de favorecer, aumentar, suscitar e estimular novas discórdias, sedições e guerras entre os príncipes e povos do império, as quais põem em perigo toda a Cristandade - embora a própria Verdade advirta: 'Todo reino dividido contra si mesmo cai em ruína [Mt 12,23; Lc 11,17]. Assim, eles, movidos por aquele mencionado desejo iníquo, enganosamente lançam uma parte da Cristandade, como seu instrumento, contra a outra, a fim de a destruir e a arruinar completamente, de modo que 
finalmente possam levar todos à servidão. Com efeito, essas pessoas muito más recentemente agiram tão às claras, que não podem camuflar com nenhuma desculpa o seu gesto: procuram eleger outro indivíduo como rei, divulgando publicamente falsos processos contra o imperador, os quais, no entanto, são nulos de direito."

À época da produção do tratado, no entanto, o imperador encontrava-se deposto e a casa bávara impotente diante da aliança de seus grandes inimigos. A morte do imperador e, em sucessão, aquela do próprio Guilherme de Ockham (Marsílio de Pádua havia falecido cerca de cinco anos antes) encerrou o período último período de disputas entre as duas grandes forças da Baixa Idade Média: o Império e o Papado. A partir de então, um novo fenômeno impunha-se no ocidente: a ascensão das monarquias absolutistas, fundamentadas no princípio da soberania territorial e protegidas por exércitos nacionais. $O$ Império, embora tenha resistido até o século XIX, perdeu seu caráter de poder civil universal, e jamais conseguiria sobreporse, baseando-se somente em tal concepção, a qualquer monarquia consolidada. Quanto à Igreja, passou, progressivamente, a submeter-se ao aparelho de Estado em cada uma das regiões em que se fazia presente, ao mesmo tempo que era atacada por outro flanco pela onda reformista.

A produção da obra política de Guilherme de Ockham adquire, portanto, significado, na medida em que se considera a conjuntura apresentada entre as décadas de trinta e de quarenta do século XIV. Ao definir esse conjunto de obras, Arthur McGrade afirmou que se tratava de uma série de escritos compilados na edição de sua Opera Política, a qual não incluía nada do que o menorita havia escrito em Oxford ou Avinhão uma vez que se encontrava, por essa época, envolvido com suas formulações filosóficas e teológicas, na aspiração a uma cátedra na Universidade britânica -, e incluía tudo, à exceção de dois tratados de lógica, que teria escrito em Munique ${ }^{\mathrm{xxx}}$ - a partir do ano de 1328, quando de sua fuga do convento franciscano de Avinhão, juntamente com outros frades menores, em direção à 
corte de Luís da Baviera ${ }^{\mathrm{xxx}}$. Dessa forma, podemos concluir que toda a produção política de Guilherme de Ockham realizou-se em função de circunstâncias presentes. Conseqüentemente, como aponta De Boni, não se observa, no conjunto dessas obras, a sistematização de uma teoria política, uma vez que todas elas devem ser lidas à luz do contexto em que foram produzidas ${ }^{\mathrm{xxxii}}$. Trata-se, portanto, de uma produção fundamentalmente polêmica, em que os aspectos teóricos surgem de maneira difusa, em detrimento de uma teoria geral.

Nesse contexto, Guilherme de Ockham elaborou uma produção polêmico-política significativa do conjunto das transformações sociais e políticas ocorridas naquele momento. É justamente no cruzamento da questão da pobreza com a causa de Luís da Baviera que se encontra o eixo da polêmica desenvolvida pelo menorita ao longo de seus vários tratados de natureza política. Dessa forma, no entender do frade, ambas as lutas - aquela da Ordem Franciscana (ou de parte dela) relacionada à pobreza, bem como aquela do imperador contra o papa - perfaziam aspectos de um só problema: a questão da defesa dos direitos invioláveis. De acordo com Boehner, no entender de Ockham, os franciscanos lutavam por um direito garantido pela Santa Escritura e também por decretos de papas anteriores, ao passo que o imperador lutava por um direito garantido pelas leis divina e natural ${ }^{\text {xxxiii }}$.

Tendo como primeiro objetivo atacar as posturas do papa João XXII (e, posteriormente, de seus dois sucessores, Bento XII e Clemente VI) - incluindo suas determinações acerca dos Espirituais Franciscanos - e, paralelamente, visando à defesa do poder imperial e do poder civil em geral, a chamada obra política de Guilherme de Ockham estabelecia, em suas linhas fundamentais, a positividade do poder temporal. O meio pelo qual o fez foi, essencialmente, aquele da negação. Ou seja, em suas obras de caráter político, o menorita dedicou-se a estabelecer qual fossem o poder do imperador e os poderes civis em geral por intermédio do estabelecimento de limites ao poder papal. 
Do ponto de vista histórico, a perspectiva de delimitar as esferas de atuação do regnum e do sacerdotium, estabelecida pelo frade inglês e por alguns de seus contemporâneos, revelouse extremamente original. $E$, no entanto, tratava-se de concepções radicadas nas condições históricas do século XIV. Com efeito, a idéia de um contrato, estabelecido a partir de um consenso social, a fim de constituir os governantes e atribuirlhes o poder - o qual, em contrapartida, somente poderia ter sua origem em Deus -, representava, no conjunto da sociedade cristã medieval, um elemento a um tempo inovador e profundamente tributário da tradição. A concepção de que o poder não se originava nem exclusivamente da lei divina e tampouco meramente da lei natural, mas tinha por origem direta o povo tal pressuposto transformava Ockham num possível fundador (embora de maneira absolutamente involuntária) da ciência política. Com efeito, a afirmação da independência do poder civil e da origem popular do poder aproximava-o, indubitavelmente, de Marsílio de Pádua. Some-se a isso que ambos se encontravam na corte de Luís da Baviera, opondo-se às políticas papais.

Da mesma forma, em contrapartida, ao partir de um referencial teológico para conduzir toda a discussão a respeito da relação entre os poderes, identificava-se a seus companheiros de hábito, remontando a Boaventura. E ainda, a concepção de todo poder enquanto serviço, fosse ele a autoridade civil ou a sacerdotal, fincava suas profundas raízes nas concepções altomedievais, com destaque para São Gregório Magno - papa que tornou corrente o uso da expressão servus servourum Dei para definir o bispo de Roma, e que segue sendo, até hoje, um dos títulos do sumo-potífice. Por fim, na medida em que se utilizava da mesma matriz - a Sagrada Escritura, os pais da Igreja e as decretais -, aproximava-se dos próprios defensores da plenitudo potestatis papal. 
MAGALHÃES, Ana Paula Tavares. The Avignon papacy and the civil powers: the decades of the thirties and forties of the $14^{\text {th }}$ century from three works by William of Ockham. História, v.27, n.2, p.223-251, 2008.

\begin{abstract}
The denial of the so-called pope's plenitude potestatis by the English Franciscan William of Ockham belongs historically to the great movement of the fall of the Empire as a universal power, and the progressive search for laicization of political problems. Such a movement occurred between the 13th and 14th centuries, and resulted in changes in the conception of papal authority. Thus, controversies between regnum and sacerdotium would change into conflicts between the pope and the rising monarchies such as the King of France evident in the dispute between Boniface VIII and Philip IV of France. Furthermore the new solutions would become more favorable toward civil powers than toward papal authority. A notable aspect of the growth of the power and prestige of the monarchies was the actual transference of the papacy to the French city, Avignon, while under the power of Pope Clement V in the year 1309. This pope heeded well to the will of King Philip IV of France, who, as his successors that followed, used the Catholic Church against his political enemies. One of the highest points of this alliance occurred during the pontificate of Clement VI (1342-1352), who supported the French King, Philip VI, against his cousin, the English King, Edward III, during the Hundred Years' War; and finally, his hostility contributed to the fall of the Emperor, Ludwig the Bavarian. In this work, I evaluate the relationship between the Avignon papacy and civil powers (the Kingdoms of France and England, and the Empire) during the thirties and the forties of the $14^{\text {th }}$ century. In addition, we will analise the works: Can the Ruler, Advice about a Marriage Case, and On the Power of the Emperors and the Pontiffs by William of Ockham.
\end{abstract}

Keywords: The Avignon papacy; Ludwig the Bavarian; the Kingdom of France. 


\section{NOTAS}

1 A expressão plenitudo potestatis sofreu uma evolução desde suas primeiras aparições nos documentos pontifícios até o período em questão. No século XIV, era utilizada entre teólogos e juristas a fim de aludir a um poder absoluto exercido pelos pontífices quer no âmbito espiritual quer no âmbito temporal.

2 ESTÊVÃO, J.C. - Sobre a liberdade em Guilherme de Ockham. Tese de Doutorado. USP, 1995.

3 FALBEL N. - Os Espirituais Franciscanos. São Paulo: Perspectiva: FAPESP: EDUSP, 1995, p. 192.

4 PACAUT, M. - La théocratie: l'Église et le Pouvoir au Moyen Age. Paris : Desclée, 1989, p. 136.

${ }^{5}$ No primeiro litígio, datado de 1296, o rei criou um imposto sobre os bens do clero para financiar sua guerra de conquista na Gasconha (o precedente havia sido aberto com Inocêncio III, que taxara o clero para financiar as Cruzadas). O evento conduziu a um protesto da ordem Cisterciense, e Bonifácio lançou a decretal Clericis laicos (24/02/1296), na qual interditava a taxação dos clérigos em geral e determinava que nenhum regulamento podia ser feito sem o consentimento da Santa Sé, sob pena de excomunhão. Muito provavelmente sem motivação papal, o rei proibiu a saída de dinheiro do reino, medida que o papa considerou contra si. Lançou a bula Ineffabilis amor (20/09/1296), em que, em meio a protestos de amizade, acusava o rei de não seguir o exemplo de seus pais, conduzindo-se por atos injustos e intempestivos, alguns resultando na guerra contra a Inglaterra, que arriscava também a provocar um grave conflito contra a Igreja. O rei não respondeu, e o papa recuou, lançando a bula Etsi de statu (31/07/1297), que determinava que as medidas da Clericis laicos não deveriam ser interpretadas de forma estrita e que os clérigos poderiam fazer doações ao rei. Iniciou-se, então, o segundo litígio. Em 1301, o rei afastou o bispo de Pamiers, Bernardo Saisset, acusado de intriga, heresia e blasfêmia. O prelado havia sido nomeado dois anos antes por Bonifácio, seu amigo de longa data, quando a cidade tornou-se sede de bispado. A reação exasperada provocou a acolhida de seus inimigos, os cardeais Colônia (que ele havia excomungado e dos quais havia confiscado os bens) na França. O papa convocou, então, os bispos franceses em Roma para deliberar sobre a reforma do rei e do reino. Lançou a bula Ausculta fili (05/12/1301), em que chamou Filipe a fazerse representar nessa assembléia. E exigiu submissão do monarca ao papa em detrimento de suas pretensões de independência de seu 
poder. Os legistas do rei elaboraram um resumo violento da bula, com conclusões em fórmulas brutais, que fizeram circular pelo reino. Em abril de 1302, uma assembléia de nobres e de clérigos reprovou as pretensões pontificais. Em 18 de novembro de 1302, o papa lançou a bula Unam sanctam - praticamente uma transcrição do mais célebre tratado de Egídio Romano, o encomiasta do poder papal De ecclesiastica potestate (1301-1302) -, pela qual o rei deveria submeterse. E o cardeal João Lemoine deveria exigir-lhe satisfação, sob pena de excomunhão. O rei, então, nomeou seu conselheiro Guilherme de Nogaret, que dirigiu duras acusações contra o papa (heresia, perjúrio), concluindo que o rei da França, defensor dos interesses da Igreja, deveria reunir um exército para julgá-lo e depô-lo como intruso. Este dirigiu-se à Itália para deter Bonifácio. Em 07/09/1303, em Anagni, o papa foi insultado, talvez agredido. Foi libertado pela população, mas morreu em seguida, em Roma (11/10). De acordo com a argumentação expressa na bula Unam sanctam, não haveria dois poderes (como até então haviam sustentado os teóricos que serviram de base para a monarquia pontifícia dos Inocêncios). Tratava-se, pois, da reductio ad unum. A missão confiada por Cristo à Igreja era guiar homens à salvação. A Igreja, por sua vez, era uma, resultando que o papa, vigário do Cristo, que era seu único chefe, possuía todos os poderes necessários para atingir tal objetivo. Como conseqüência, atribuíam-selhe poderes ilimitados dos pontos de vista temporal e espiritual. E ainda: afirmar a independência do poder temporal significava a admissão da existência de dois princípios, tendo como resultado a rejeição do dogma da unidade (de maneira semelhante à heresia maniquéia). Dever-se-ia conceder, ainda, com base em toda uma argumentação de ascendência neoplatônica, que os estados provinham do papado, bem como cabia a ele controlá-los e julgá-los.

${ }^{6}$ Trata-se das seguintes bulas:

Ad conditorem canonum (8 de dezembro de 1322), em que afirmava que Nicolau III, ao estabelecer a Igreja Romana como proprietária dos bens usados pelos franciscanos, embora movido por ideais piedosos, incorrera numa impossibilidade racional e jurídica, tendo em vista o uso daquelas coisas que se consomem pelo próprio uso, tais como roupas e alimentos.

Cum inter nonnullos (12 de novembro de 1323), em que declarava consistir em heresia a afirmação de que Cristo e os Apóstolos nada haviam possuído. 
Quia quorundam mentes (10 de novembro de 1324), em que afirmava que suas duas bulas anteriores eram condizentes com a Exiit qui seminat, de Nicolau III, ao mesmo tempo que sua autoridade bastava para definir a questão.

${ }^{7}$ Conforme a bula Exiit qui seminat, de Nicolau III, emanada em 1279.

${ }^{8}$ Cf. DUFFY, E. - Santos e pecadores: História dos papas. Trad. Luiz Antônio Araújo. São Paulo: Cosac\&Naify, 1998, p. 125.

${ }^{9} \mathrm{O}$ decreto estabelecia, ainda, que a eleição pontifícia dar-se-ia por intermédio de escolha do colégio dos cardeais, cabendo ao restante do clero e ao povo romano somente a aclamação do pontífice. Cf. Monumenta Germania Historica, Constitutionum et acta publica imperatorum et regum, t. 1, p. 539.

${ }^{10}$ An princeps, Consultatio de causa matrimoniali e De imperatorum et pontificum potestate, respectivamente.

${ }^{11}$ Três anos depois, ele publicou uma parte considerável do texto em questão (R. Scholz - Unberkannte kirschenpolitische Streitschriften aus der Zeit Ludwigs des Bayern, I, Roma, 1911, pp. 167-176 (análise); II, 1914, pp. 432-453 (texto).

${ }^{12}$ Conforme IV Concílio de Latrão e a bula Clericis laicos (1296), de Bonifácio VIII, ensejada por aspiração semelhante, da parte de Eduardo I (1272-1307) e Filipe o Belo, àquela altura em guerra entre si.

${ }^{13}$ Muitas vezes, atribui-se a ele o seguinte título, completo, expressão de parte do conteúdo do tratado: Pode um príncipe,quando o requerem as necessidades bélicas, receber bens das igrejas, mesmo contra a vontade do papa? (An princeps pro suo succursu, scilicet guerrae, possit recipere bona ecclesiarum etiam invitu papa?).

${ }^{14}$ Cf. Pode um príncipe, in GUILHERME DE OCKHAM - Obras políticas - vol. II. Trad. José Antônio Camargo Rodrigues de Souza. Porto Alegre: EDIPUCRS/USF, 1999, p. 118. "Ostenso quod papa non habet talem plenitudinem potestatis, qualem plures sibi attribuunt, mostrandum est primo quod non obstante quocunque stato papali, prohibitione vel praecepto, sententia vel processu, praelati et clerici Anglorum subiecti ei etiam de bonis ecclesiae in guerra sua iusta auxiliari tenentur; secundo, quod ab hoc eos papa per nullum statutum, prohibitionem, praeceptum, sententiam vel processum potest prohibere." (GUILLELMI DE OCKHAM - Opera política - vol. I. Ed. H.S. Offler. Manchester: Mancuni\&Typis Universitatis, 1974 (1940), pp. 252-253.)

${ }^{15}$ IDEM, Ibidem, p. 118. "Quod Augustinus testatur expresse, qui super Ioannem, parte prima, sermone sexto circa finem, et habetur in decretis, di. Viii, c. Quo iure, ait, loquens de villis et allis rebus 
ecclesiae: Quo iure defendis villas ecclesiae, divino aut humano? Respondeant: 'Divinum ius in scripturis divinis habemus, humanum ius in legibus regum'. Unde unusquisque possidet quod possidet? Nonne iure humano? Nam iure divino: 'Domini est terra, et plenitudo eius'. Pauperes et divites Deus de uno limo fecit, et divites et pauperes uma terra supportat. Iure ergo humano dicitur: 'Haec villa mea est, haec domus mea est, hic servus meus est.'." in IDEM, Ibidem, p. 253.

16 IDEM, Ibidem, pp. 119-120. “(..) unusquisque in traditione seu collatione sive donatione rei suae potest legem, quam vult, imponere, dummodo nichil imponat, quod sit lege superiori prohibitum. (...) Ex quo evidenter infertur quod reges Anglorum et eisdem subiecti possessiones et quascunque res temporales, praecipue superabundantes, assignando ecclesiis poterant ordinare qualiter debuerint dispensari et in quos usus clerici eas teneantur expendere; quorum ordinationem, voluntatem et intentionem clerici de necessitate salutis servare tenentur, non obstante prohibitione, praecepto vel statuto cuiuscumque, qui regibus in temporalibus non est superior reputandus." in IDEM, Ibidem, pp. 253-254.

17 IDEM, Ibidem, p. 120. “(..) est interpretatio benignior, humanior, rationabilior et verosimilior amplectenda: tum quia, sicut in hiis, quae ad cultum divinum spectant, benigna est interpretatio facienda, Extra, de privilegiis, c. In hiis, ita etiam in hiis, quae ad pietatem pertinent, benignior et rationabilior interpretatio fieri debet, ut nulli sit captiosa, ff. de regulis iuris, Quotiens, sic in obscuris est interpretatio facienda, ut res magis prosit, praesertim bono communi, et ut in nullius dampnum redundet iniustum." in IDEM, Ibidem, p. 254. Os grifos são do editor.

${ }^{18}$ GUILHERME DE OCKHAM - Sobre o poder dos imperadores e dos papas, in Op. cit., pp. 215-216. "Ex hiis concluditur quod ecclesia Avinionica ordinans et disponens de rebus ecclesiasticis clericorum sive saecularium sive religiosorum aliter quam ordinaverunt illi, qui dederunt, scilicet tollendo ab eis et accipiendo sibi vel aliis tribuendo, clericis iniuriatur eisdem. Et ideo papa vel gerens se pro papa, si de bonis superabundantibus clericorum dat decimas vel aliquam aliam certam partem alicui clerico vel laico vel etiam accipit pro se ipso, ipsis iniuriam irrogat manifestam, nisi donans res huiusmodi clericiss talem papae concesserit potestatem. Et ideo, quia in privilegiis principum, qui donaverunt ecclesias, non habetur quod ipsi talem super rebus, quas dederunt ecclesiis, papae concesserunt potestatem, papa de rebus ecclesiae taliter se intromittere minime potest. Et ideo, si imperator, rex vel princeps [vult se] iuvare pro piis causis de rebus 
superabundantibus ecclesiae, quas ipse vel praedecessores sui dedit vel dederunt ecclesiis, non debet petere subsidium a papa de huiusmodi rebus, nisis forte papa ex consuetudine tolerata scienter in aliqua regione talem obtinuerit potestate; sed auctoritate propria in casu necessitatis pro piis causis potest ab ecclesiis subsidium postulare." in WILLIAM OCKHAM - Opera politica - vol. IV. Ed. H.S. Offler. Oxford: British Academy, 1997, p. 321.

${ }^{19}$ Cf. Defensor minor, XV, 1-4, ed. Brampton, pp. 46-49.

20 "Lembra-lhes que devem ser submissos aos magistrados e às autoridades, que devem ser obedientes e estar sempre prontos para qualquer trabalho honesto, que não devem difamar a ninguém, nem andar brigando, mas sejam cavalheiros e delicados para com os outros." (A Bíblia de Jerusalém - Ti 3,1). GUILHERME DE OCKHAM Consulta sobre uma questão matrimonial, in Op. cit., p. 150. “(...) cum secundum beatum Ambrosium super epistolam ad Titum: Religio christiana neminem privet de iure suo." in GUILLELMI DE OCKHAM Op. cit., p. 279.

${ }^{21}$ IDEM, Ibidem. "Cui beatus Augustinus super Ioannem alludit, dicens in persona Christi: Audite Iudaei et gentes, [audi circumcisio, \} audi praeputium, audite omnia regna terrae. Non impedio dominationem vestram in hoc mundo, quia 'regnum meum non [est] de hoc mundo'." IDEM, Ibidem, p. 278.

${ }^{22}$ IDEM, Ibidem, p. 155. "Cum igitur lex divina nequaquam prohibeat illustrissimum principem dominum Ludovicum marchionem Brandenburgensem et Margaritam ducissam Karinthiae matrimonialiter copulari, eo quod inter praedictam Margaritam et filium regis Bohemiae, cuius putabatur uxor, nunquam verum matrimonium intervenit." in GUILLELMI DE OCKHAM - Op. cit., p. 281 (para a argumentação a respeito da Lei Evangélica, vejam-se as pp. 279-280-281.)

${ }^{23}$ Londres, BL Royal ms. 10 A.XV, fl. 95r. É provável que Young tenha adotado um título já verificado em L. Wadding. A considerar essa hipótese, ele enganou-se de manuscrito, pois, ao que parece, o referido bibliógrafo pretendia referir-se ao tratado Octo quaestiones (na íntegra: Octo quaestiones de potestate papae).

${ }^{24} \mathrm{O}$ incipit explica, em parte a desproporcional extensão da parte do tratado destinada a tratar dos erros dos pontífices recentes: "Incipit quaedam apologia sive excusatio aut eciam assercio veritatis magistri Wylhelmi Occam cum ostensione errorum tunc ecclesie avionice 
tempore scismatis diebus suis durantis." (Deventer, AthenaeumBibliotheek, ms. 1, f. 1r).

${ }^{25}$ Breviloquium de potestate papae (c.1341-1342).

${ }^{26}$ Alusão a São Bernardo - De consideratione, I, 6 in Patrologia Latina $182,736$.

${ }^{27}$ GUILHERME DE OCKHAM - Sobre o poder dos imperadores e dos papas, in Op. cit., pp. 206-207. "Amplius, Romanum imperium fuit ante papatum; ergo in suo principio non fuit a papa; et per consequens nec post institutum papatum est a papa. Et ex isto sequitur quod si papa in aliquo - nisi forte petendo specialiter necessitates suas ab imperator, si est Fidelis, pro eo quod est specialiter episcopus urbis Romanae - se in aliquo intromittit de Romano imperio ipsis invitis, ad quos spectat dispositio eiusdem imperii, aliter quam de aliis regnis vel aliter quam ab imperatoribus ordinatum exstitit, sive vacante império sive non vacante, eidem iniuriatur império mittendo falcem suam in messem alienam; quia talem potestatem non obtinet super Romanum imperium neque a iure divino neque a iure humano." WILLIAM OCKHAM - Op. cit., pp. 312-313. Os grifos são do editor.

${ }^{28}$ IDEM, Ibidem, p.189. "Hinc Christus praeficiens ovibus suis beatum Petrum non dixir ei 'Tonde oves meas et fac tibi vestes de lanis earum' ; nec dixit 'Mulge oves meas, et bibe vel comede lac earum' ; nec dixit 'Macta oves meas, et manduca carnes earum'; sed dixit: Pasce oves meas, id est 'Serva, rege, custodi et servi eis, ad honorem meum et utilitatem ipsarum.'” IDEM, Ibidem, p. 297.

${ }^{29}$ IDEM, Ibidem, p. 212. "Omne regnum divisum contra se, desolabitur confovere non desinunt et augere ac novas perperam suscitare: ut sic ad desiderium suum iniquum unam partem deceptorie protrahentes, illa mediante aliam omnino destruant et prosternant, et sic tandem in servitudinem redigant universos. Haec impiissime hiis diebus tam notorie peregerunt, quod nulla possunt tergiversatione celari, dum falsis processibus et de iure nullis contra imperatorem publice divulgatis alium in regem eligi procurarunt." IDEM, Ibidem, p. 318.

30 McGRADE, A.S. - The Political Thought of William of Ockham: Personal and Institutional Principles. Cambridge: Cambridge University Press, 1974, p.3.

31 A temática político-religiosa fez suas primeiras aparições nos escritos do menorita a partir de sua fuga de Avinhão, em 26 de maio de 1328, juntamente com o então geral da Ordem Franciscana, Miguel de Cesena, e outros frades menores, com os quais o Venerabilis Inceptor passou a condividir a sorte de perseguido pela excomunhão lançada 
pelo papa João XXII (1318-1334). O ano de 1328 consiste, com efeito, num ponto de clivagem; ele assinalou uma mudança de preocupação no conjunto do pensamento ockhamiano: passou-se, então, de uma profícua produção de tratados filosóficos - encontrava-se, então, ligado à vida acadêmica, almejando a obtenção de uma cátedra em Oxford - a preocupações de cunho político, que originaram um vasto conjunto de obras.

Sua estada em Avinhão, iniciada em 1324, deveu-se a suspeitas que pesavam sobre seu Comentário às Sentenças (comentário aos quatro livros das Sentenças de Pedro Lombardo, pré-requisito para a obtenção do título de Mestre em Teologia), tendo como resultado sua convocação perante o tribunal pontifício. Ockham permaneceu no convento franciscano daquela localidade até o ano de 1328 sem, contudo, ser levado a julgamento. Em contrapartida, travou contato com a controvérsia a respeito da pobreza, que então opunha parte da Ordem Franciscana e a cúria papal. Os frades rebeldes, liderados por seu ministro geral Miguel de Cesena, sustentavam que Cristo e os apóstolos nada haviam possuído, quer em caráter privado, quer em comum. A eles faziam face as constituições pontifícias de João XXII, que afirmavam que Cristo e os apóstolos haviam sido possuidores.

Comentando as referidas constituições, Guilherme de Ockham constatou que nelas havia quamplura hereticalia, erronea, stulta, ridiculosa, fantastica, insania et diffamatoria fidei orthodoxe, bonis moribus, rationi naturali, experientie certe et caritati fraterne contraria pariter et adversa patenter. A partir de então, o menorita inglês encontrava-se envolvido na querela da pobreza, e seu destino vinculado às vicissitudes do grupo dos Franciscanos perseguidos pelo papa. Convencido de que o papa incorrera em heresia, passou a fazerlhe intensa oposição, a qual deveria consistir em elemento recorrente em seus escritos até o fim de sua vida.

O grupo pediu, então, asilo junto ao imperador Luís da Baviera, que se encontrava em luta contra o papa, o qual não reconhecia sua soberania sobre o Sacro Império Romano-Germânico. Ao mesmo tempo que pretendia que o poder do imperador proviesse do papado, João XXII negava-se a conceder-lhe a investidura. Cioso de assegurar sua independência em vista de um papa que pretendia tanto controlá-lo quanto contestá-lo, o bávaro cercou-se de frades rebeldes em Munique, e os escritos político-religiosos proliferaram. É justamente no cruzamento da questão da pobreza com a causa de Luís da Baviera que se encontra o eixo da polêmica desenvolvida por Ockham ao longo de 
seus vários tratados. A qualidade de herético de João XXII consistiu no tema central de todos os tratados do menorita inglês até o ano de 1338 (quando o Império propriamente dito tornou-se o cerne das discussões). Assim, temos: Allegationes religiosorum virorum, Opus nonaginta dierum, Dialogus prima pars, Epistola ad fratres minores in capitulo apud Assisium congregatos, De dogmatibus papae Johannis XXII, Tractatus contra Iohannem XXII, Tractatus contra Benedictum XII (no qual acusa esse papa de dar continuidade aos equívocos de seu antecessor, João XXII), Compendium errorum papae Johannis XXII (ainda que após a morte daquele pontífice). Ainda no corpus de escritos posterior a 1338, podem-se constatar capítulos destinados a tratar o tema. Em seu último tratado (examinado ao longo deste trabalho), De Imperatorum et Pontificum potestate, escrito em 1347, ano provável de sua morte, Guilherme de Ockham dedicou às heresias de João XXII uma parte proporcionalmente muito extensa em relação àquelas em que se propôs a tratar as relações entre os dois poderes. (V. MAGALHÃES, A.P. - "A questão da plenitudo potestatis em Guilherme de Ockham: o significado de sua obra política" in Relações de poder, educação e cultura na Antigüidade e Idade Média, estudos em homenagem ao Professor Daniel Valle Ribeiro: I CIEAM, VII CEAM. Org. Ruy de Oliveira Andrade Filho. Santana de Parnaíba, SP: Sollis, 2005, pp. 479-490.)

${ }^{32}$ DE BONI, L.A. - De Abelardo a Lutero: Estudos sobre Filosofia Prática na Idade Média. Porto Alegre: EDIPUCRS, 2003, pp. 285-286.

${ }^{33}$ BOEHNER, Ph. - "Ockham's political ideas" in BUYTAERT, E.M. (ed.)

- Collected articles on Ockham. Nova Iorque: The Franciscan Institute St. Bonaventure, 1958, p. 442.

Artigo recebido em 08/2008. Aprovado em 10/2008. 


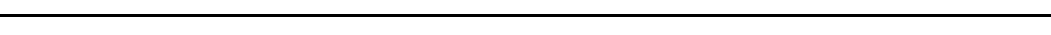

